\title{
Distortion Prediction Model of Enterprise Accounting Information Based on the Principal Components
}

\author{
Hui $\mathrm{QI}^{1, \mathrm{a}}$ \\ ${ }^{1}$ Sichuan electric vocational and technical college, Chengdu 610072, China \\ aHuiQI1020@yeah.net
}

Keywords: distortion prediction model; accounting information; enterprises; study; accounting information distortion;

\begin{abstract}
The identification of enterprise accounting information distortion is one of the difficult problems of financial research at home and abroad. This paper uses principal component analysis of multivariate statistical analysis method, establishes a prediction of enterprise accounting information distortion of the new model -- the principal component forecast model, and the Shanghai and Shenzhen two city annual report issued by accounting firm "negative opinion" or "declined to comment" listing corporation is defined as "the distortion of accounting information, enterprises" selection 44 the distortion of accounting information of enterprises and should be relatively with the 44 non distortion of accounting information in enterprises total 88 companies as the research sample, the author makes an empirical test on the main components of listing corporation accounting information distortion prediction model. At 1 , the distortion of accounting information refers to accounting information doesn't reflect the real economic activities. Public accounting information distortion of the inevitable consequence of the decision to the relevant interest groups related to the adverse effects.
\end{abstract}

\section{Introduction}

Since the China securities market opened, many listing corporation suffer the CSRC administrative penalties because of the distortion of accounting information, such as the Lantian stock company, Guangxia stock company, and this is just the tip of the iceberg of accounting information distortion. Fool is known as the Modern Corporation governance structure of classical USA listing Corporation also can not escape the accounting information fraud, according to the "business weekly" reported in twentieth Century, since the late 90's, the scope and scale of financial scandals Usa Inc exposure than at any time since the great depression.[2]

\section{The definition of accounting information}

Accounting information generally refers to the accounting units through a variety of professional accounting accounts, table and other forms to stakeholders and users of the information revealed the entity's financial position and operating results of information. Accounting information is the most intuitive way of understanding of the enterprise is the most convenient persons outside the business, so the quality of information quality, the enterprise accounting distortion or not directly related to the interests of stakeholders such as Sapium [1] decision-making information users. Provide high quality, convenient use of accounting information is the obligation and responsibility accounting unit. The current "accounting standards for business enterprises" in China and "small business accounting standards"[1], put forward strict requirements of accounting information quality are provided by the enterprise. Among them, which requires enterprises to provide accounting information must be relevant, reliable, true, and elbow, neutral, comparable and useful. And ask the enterprise to provide the accounting information is true, is the most basic accounting information quality requirements. The distortion of accounting information, the type of the distortion of accounting information, is refers to the accounting unit to stakeholders or other information submitted by the users of accounting information due to various subjective or objective, 
objective facts and the unit's departure from, cannot reflect the unit's assets condition and results of operations

\section{Research ideas and research methods}

Research ideas: first of all, this paper is a general using of a certain method to determine the sample of the study; secondly, it is on the basis of selecting and determining the financial index; thirdly, discriminant analysis is performed using SPSS [4]statistical software; finally, it is to build the model and test.

(1)We selected the study samples. Non-accounting information distortion "company selects a certain number of" accounting information "companies and should be relative with the same number of" as the research sample. The samples were divided into two groups, one the estimation sample, another group of test sample. Construction of discrimination model estimation sample group of data is used, and the test sample data are used to test the effectiveness of the model. [2]

(2)Analysis of financial data is to identify the estimation sample. Discriminant analysis is a statistical method to the research object of the class discrimination. Discriminant analysis classification of objects observed must be known and some said observation value of the variable. Discriminant analysis is to choose the number can provide more information in and establish discriminant function, the discriminant function is derived to estimate sample and test sample classification error rate is reduced to a minimum. The general form of the discriminant function is:

$$
\mathrm{Z}=\mathrm{K} 1+\mathrm{X} 1+\mathrm{K} 2 \mathrm{X} 2+\ldots+\mathrm{KiXi} \quad \text { (F.1) [3] }
$$

The $\mathrm{Ki}(\mathrm{i}=1,2,3, \ldots \mathrm{S})$ is for distinguishing the coefficient of each variable, $\mathrm{Z}$ discriminant, $\mathrm{X} 1$, $\mathrm{X} 2, \mathrm{X} 3, \ldots \mathrm{Xi}$ is a reflection of the characteristic variables of research variables. [3]

(3)Estimation samples in this group discrimination of financial situation, and then selects the segmentation points. The estimated financial index data into the standard sample enterprises (F.1) get the enterprise accounting information distortion of the discriminant. Clearly discriminate higher representative of accounting information quality the better enterprise; on the contrary, discriminant is lower the quality of accounting information of enterprises worse. Then the estimation sample enterprises select the classification error rate of accounting information distortion of enterprise accounting information distortion and non minimum separation of enterprises.

\section{The empirical test and discriminant model of accounting information distortion}

The selection criteria are 1999-2003 years of continuous operation, no cancellation of the qualifications listed listing corporation: a. the accounting distortion analysis of samples. Because our country stock market started late, the financial fraud was found in companies less, many samples occurs in many years ago, and the current situation is big, is not conducive to the correct understanding of the current characteristics of the financial fraud. We use the opinions of the annual audit report of 1999-2003, identified the 59 Sample Firms (including the merger of some times "declined to comment" or "negative opinion" of the same company sample in order to improve the information content of the sample). the data of financial report and the "profit * cash flow $>0$ " the financial report of the company. This standard is given to the cash flow of $>0$ is the basis of company policy operation, if the company profit and cash flow of $>0<0$ or $=0$, then the company has great accrued earnings suspected fraud; if the profit and cash flow $<0>0$, then the company is facing significant management crisis, this company is likely to remain at the same time, the double difficulties the financial crisis and the management of crisis, through short-term debt and other methods to beautify the short-term financial situation, suspected fraud is also great. [3]

In order to analyze the financial ratios can distortion listing Corporation, listing Corporation and non accounting information distortion of accounting information under difference effectively, we 88 estimate sample listing Corporation respectively 9 financial ratios for single variable $\mathrm{T}$ test, the test results are shown in Table 2:[2] 
Table 2. The results of $\mathbf{T}$ tests

\begin{tabular}{|l|l|l|l|l|l|}
\hline Financial ratio & Company type & $\begin{array}{l}\text { average } \\
\text { value }\end{array}$ & $\begin{array}{l}\text { Standard } \\
\text { deviation }\end{array}$ & T value & $\begin{array}{l}\text { T-test } \\
\text { probability }\end{array}$ \\
\hline $\begin{array}{l}\text { Assets and liabilities } \\
\text { rate }\end{array}$ & $\begin{array}{l}\text { Distortion } \\
\text { non-distortion }\end{array}$ & $\begin{array}{l}1.8947 \\
0.502\end{array}$ & $\begin{array}{l}2.333 \\
0.225\end{array}$ & 3.9 & 0.00 \\
\hline Equity ratio distortion & Distortion & 17.539 & 94.645 & 1.151 & 0.256 \\
& non-distortion & 1.023 & 0.6337 & & \\
\hline $\begin{array}{l}\text { Asset } \\
\text { interest rate }\end{array}$ & Distortion & -1.0199 & 2.2059 & -3.41 & 0.001 \\
\hline Asset turnover ratio & non-distortion & 0.1112 & 0.126 & & \\
\hline inventory of assets & Distortion & 0.3054 & 0.3678 & -5.347 & 0.000 \\
rate & Distortion & 0.7292 & 0.43 & & \\
\hline The price margin & non-distortion & 0.1309 & 0.1713 & 0.319 & 0.751 \\
& Distortion & -24.4299 & 124.795 & -1.304 & 0.199 \\
\hline Sales profit ratio & non-distortion & 0.1055 & 0.0764 & & \\
\hline Working capital ratio & Distortion & 2.994 & 10.769 & 1.769 & 0.078 \\
& non-distortion & 0.156 & 0.2053 & & \\
\hline $\begin{array}{l}\text { Accounts receivable/ } \\
\text { inventory }\end{array}$ & non-distortion & -1.2544 & 2.47373 & -3.607 & 0.001 \\
& non-distortion & 0.0558 & 0.2172 & & \\
\hline
\end{tabular}

According to the results of $\mathrm{T}$ test, the distortion of the accounting information and non-distortion of accounting information of the listing corporation listing are asset liability ratio, asset margin, asset turnover, credit ratio, working capital ratio and accounts receivable / inventories are obvious differences. According to the above analysis, each of the 9 financial ratios are analyzed, according to the ability to distinguish between the effective accounting information distortion of accounting information distortion and non listing Corporation listing Corporation, the final choice as the distortion of accounting information in predicting financial index model are: the ratio of assets to liabilities, assets and gross margin, asset turnover, credit ratio, working capital ratio and accounts receivable / inventory.

\section{Establishment and analysis of the models}

The process of discriminant analysis are classified according to the known $y=0$ and $y=1$ measurements, and show that the concept of measurement characteristics of financial ratio variables, the discriminant function is derived, and the view of the measurement of the variable value back to the generation to the discriminant function to. Through discriminant analysis, from the 6 characteristics of financial ratio variables finally derived only discriminant function of four variables, i.e.:

$$
\mathrm{Z}=-0.173 \times 1+0.799 \times 2+0.7 \times 3-0.25 \times 4 \text { (F.3) }
$$

In the formula where $\mathrm{X} 1$ is the asset of gross margin, $\mathrm{X} 2$ as the asset turnover ratio, $\mathrm{X} 3$ as working capital ratio X4 as accounts receivable / inventory.

\section{Conclusion}

Through above discriminant analysis, we may safely draw the conclusion, discriminant model in distinguishing the listing Corporation accounting information distortion with a strong confidence, but also, if using the model of listing Corporation financial ratio index were observed continuously dynamic analysis, pay attention to the development trend of discrimination is worth, and practicality it is more. Of course, in the use of discriminant model for the distortion of accounting information 
discrimination, also has its limitations, some at the same time, due to the listing Corporation sample data collection limitations, we are unable to track these samples to check for several consecutive years, but the methods and ideas have given us a good start.

\section{References}

[1] Green, B.P., Assessing the risk of management fraud neural network [M], A Journal of Praectice and Theory, 1997, 14-28.

[2] Fanning, Neural detection of management fraud using published financial data [M], International Journal of Intelligent System in Accounting, Finance and management, 2000,21-41.

[3] Liu shuwei, Recognition technology of listed companies false financial statements [M], Economy and Science, 2002, 47-69.

[4] Spathis, Detecting False Financial Statements Using [J], Management Auditing Journal, 2000, (17): 179-191.

[5] Linda Ragland,Usha Ramachandran. Towards an understanding of excel functional skills needed for a career in public accounting: Perceptions from public accountants and accounting students[J]. Journal of Accounting Education,2014 